\title{
Micropygomyia (Sauromyia) petari, a new species of Phlebotominae (Diptera, Psychodidae) from Vale do Ribeira, São Paulo State, Brazil
}

Eunice A. Bianchi Galati ${ }^{1}$

Ana Maria Marassá ${ }^{2}$

Rute Maria Gonçalves de Andrade ${ }^{3}$

Aвstract. Micropygomyia (Sauromyia) petari sp. nov. (Diptera, Psychodidae, Phlebotominae) from speleological province
of the Vale do Ribeira, São Paulo State, Brazil, is described and illustrated. This new taxon belongs to oswaldoi series.

KeYwords. Micropygomyia (Sauromyia) petari sp. nov.; Phlebotominae; Psychodidae; taxonomy; Vale do Ribeira.

\section{INTRODUCTION}

The new phlebotomine species of Micropygomyia Barretto, 1962 was captured during ecological study that was carried out between January 2001 and December 2002, in an Atlantic forest reserve, 260 - $890 \mathrm{~m}$ above sea level, $24^{\circ} 16^{\prime}-24^{\circ} 32^{\prime} \mathrm{S}$, $48^{\circ} 25^{\prime}-48^{\circ} 42^{\prime} \mathrm{W}$, in caves and the surrounding forested areas, in the speleological province of the Vale do Ribeira situated at the Serra de Paranapiacaba, in the south of São Paulo State, Brazil.

This reserve is located in a transitional area between dense umbriferous submontane forest and mixed umbriferous submontane forest (VELOSo et al. 1991), with calcareous rock formation containing large caves.

BARRETo (1962) created the subgenus Lutzomyia (Micropygomyia) for the cayennensis species-group Fairchild, 1955. GALATI (1995) raised up Micropygomyia to genus level, within the subtribe Sergentomyiina, in which included the subgenera: the monospecific M. (Silvamyia) Galati 1995, M. (Coquillettimyia) Galati, 1995 and M. (Sauromyia) Artemiev, 1991. She divided this later into the atroclavata series Fairchild, 1955 and the oswaldoi series Barretto, 1962. This series when created by BARRETO (1962) was included in the subgenus Lutzomyia (Helcocyrtomyia) Barretto, 1962. Martins et al.
(1978) and Dias et al. (1991) accepted these groupings proposed by BARRETo (1962) and THEODOR (1965), Lewis et al. (1977) and Young \& Duncan (1994) adopted the oswaldoi species-group, also within the genus Lutzomyia.

Both sexes of Micropygomyia may be characterized as follows: $5^{\text {th }}$ palpomere longer than $3^{\text {rd }}$; and the $2^{\text {nd }}$ palpomere equivalent to or slightly shorter than the $4^{\text {th }}$; Newstead's spines grouped in the basal half of the $3^{\text {rd }}$ palpomere, absence of papilla on the antennomere $\mathrm{AV}$; ventrocervical sensillae present and setae on the anterior margin of katepisternum absent. Male: gonostyle with three, four or five major spines and absence of pre-apical seta; gonocoxite with or without tufts of setae; lateral lobes with round tip and thinner than gonocoxite; simple paramere; presence of tergal at least on some tergites. Female: hypopharynx with poorly delineated teeth; lacinia with external teeth disposed in a single and longitudinal or transversal row, cibarium with four or more posterior horizontal teeth and incomplete sclerotised arch; pharynx armed or not; common duct of spermathecae absent or short, individual ducts long and spermathecae with annulation or vesicular.

The subgenus M. (Sauromyia) is characterized by males having AIII shorter than the head length; style with four or five major spines implanted on the apical middle, gonocoxite with or without tufts of setae on its basal region. Females with

\footnotetext{
1. Departamento de Epidemiologia, Faculdade de Saúde Pública, Universidade de São Paulo. Avenida Dr. Arnaldo 715, 01246-904 São Paulo-SP, Brazil. E-mail: egalati@usp.br

2. Secção de Parasitoses Sistêmicas, Instituto Adolpho Lutz. Avenida Dr. Arnaldo 355, 01246-902, São Paulo-SP, Brazil. E-mail: armm@osite.com.br

3. Laboratório de Imunoquímica, Instituto Butantan. Rua Vital Brasil 1500, 05503-900, São Paulo-SP, Brazil. E-mail: rutemga@netscape.net
} 
four posterior (horizontal) teeth; the ascoids' tips extend beyond the middle of AIV. Males with gonostyle having five spines and females without strong sclerotised transversal striation on the pharynx are included in the oswaldoi series and gonostyle with four spines and pharynx with strong sclerotized transversal striation in the atroclavata series.

The captures have been undertaken with black and/or white modified Shannon traps (GALATI et al. 2001) and with automatic light traps (NATAL et al. 1991) modified (ALTm), in which the collection chamber is external and linked to the body of the trap by a cotton sleeve $c a .20 \mathrm{~cm}$ long, with a plastic casing.

After clearing by the method described by FoRATTINI (1973) and mounting on microscope slides in NC medium (CERQUEIRA 1943), the specimens were measured with a Zeiss ${ }^{\circledR}$ eye-piece calibrated according to a standard Zeiss ${ }^{\circledR}$ scale and drawn with an Olympus ${ }^{\circledR}$ camera lucida. All measurements are given in micrometers. The measurements of paratypes are given in parentheses. The species nomenclature follows GaLATI (1995). The type material is deposited in the entomological collection of the Faculdade de Saúde Pública da Universidade de São Paulo (FSP/USP).

\section{Micropygomyia (Sauromyia) petari sp. nov.} (Figs. 1-16)

Holotype (male): total body length $2690(2727 \pm 167 ; n=4)$. Predominantly pale brown, with pronotum and mesonotum dark brown and the basal part of katepisternum and katepimerum slightly light brown.

Head (Fig. 1): length $330(326 \pm 17 ; n=4)$; width 280 ( $284 \pm$ $14 ; n=3)$. Eyes: length $153(152 \pm 5 ; n=4)$; width $80(91 \pm 4$; $n$ $=4)$ (frontal view). Interocular distance $115(113 \pm 5 ; n=3)$. Interocular suture separated from antennal suture. Clypeus length $118(114 \pm 11 ; n=4)$. Antennomere lengths: AIII 270 (281 $\pm 12 ; n=4), \operatorname{AIV} 115(121 \pm 8 ; n=4), \operatorname{AV} 120(123 \pm 7 ; n=4)$, AXV $56(50 ; n=1)$ and AXVI $55(54 ; n=1)$. Antennal formula AIII 2, AXIV-AXV 1, AXVI 0; ascoids simple and short, those on AIV reaching the middle of the segment (Fig. 4); papilla absent on AV (Fig. 5) and AXIII. Length of the palpomeres: I 30 (31 $\pm 5 ; n=4)$, II $113(119 \pm 8 ; n=3)$, III $155(161 \pm 8 ; n=3)$, IV 120 (128 $\pm 6 ; n=3)$, V 315 (335; $n=1)$. Palpal formula: 1.2.4.3.5. Newstead's spines (about 3 ) on median third of palpomere III (Fig. 3) and absent $(0,1,2 ; n=4)$ from palpomere II. Labroepipharynx $162(159 \pm 11 ; n=4)$ long. Labial sutures united.

Cervix: ventrocervical sensillae present.

Thorax: mesonotum length $450(466 \pm 35 ; n=4)$. Pleura with 4 (2-5 proepimeral setae; $n=4)$ and $12(9-13 ; n=4)$ upper anepisternal setae. Setae absent on the anterior katepisternum margin. Suture between katepimerum and metepisternum absent. Wing (Fig. 13): length $1680(1740 \pm 101 ; n=4)$, width $420(429 \pm 37 ; n=4)$. Length of vein sections: alpha 350 (368 \pm 22; $\mathrm{n}=4)$, beta $250(278 \pm 26 ; \mathrm{n}=4)$, gamma $300(278 \pm 43 ; \mathrm{n}=$ 4), delta $90(115 \pm 21 ; n=4)$, pi $140(153 \pm 12 ; n=4), R_{5} 1130$ $(1185 \pm 75 ; n=4)$. Length of femora, tibiae, basitarsi and tarsi II+III+IV+V: foreleg $690(710 \pm 85 ; n=2), 820(833 \pm 95 ; n=2)$,
$490(500 \pm 71 ; \mathrm{n}=2), 610(585 \pm 92 ; \mathrm{n}=2)$; midleg $670(650 ; \mathrm{n}=$ 1), 950 (910; $n=1), 560(530 ; n=1), 650(590 ; n=1)$; hindleg 740 $(700 ; n=1), 1150(1100 ; n=1), 640(610 ; n=1), 680(640 ; n=1)$.

Abdomen $1520(1527 \pm 120 ; n=4)$ long. Tergites III-VII with tergal papillae. Terminalia (Fig. 14): gonostyle $112(119 \pm 8 ; n=$ 4) long, with 5 major spines; the spines having the following disposition: two apical, the upper external on the 5th apical part of the structure, the lower external and the internal beyond the middle of the structure. Gonocoxite (218 long $x 42$ wide) $(212 \pm 11 \times 46 \pm 7 ; n=4)$ with $2(2-4 ; n=4)$ basal isolated setae. Paramere simple and digitiform; dorsal margin length $162(158 \pm$ $7 ; n=4)$ and the ventral margin length $172(180 \pm 7 ; n=4)$ with setae in the apical half. Conical aedeagus, dorsal margin length $92(87 \pm 6 ; n=4)$ and ventral margin length $55(52 \pm 9 ; n=4)$. Lateral lobe length $185(195 \pm 5 ; n=4)$; width $18(21 \pm 2 ; n=4)$. Genital pump: $133(147 \pm 5 ; n=4)$ long; piston length 118 (116 $\pm 4 ; n=4)$ and chamber length $45(47 \pm 5 ; n=4)$. Genital filaments length $345(354 \pm 20 ; n=4)$ or $2.59(2.41 \pm 0.1 ; n=4)$ times the length of genital pump. Tip of genital filaments simple and bevelled (Fig. 15). Cercus $138(141 \pm 8 ; n=4)$ long.

Paratype (female): total body length ca. 2540 (2536 \pm 176 ; $n$ $=8)$. General coloration as in the male.

Head (Fig. 2): length 380 ( $370 \pm 13 ; n=10)$; width 295 (308 \pm $13 ; n=10)$. Eyes: length $170(168 \pm 8 ; n=10)$; width $88(92 \pm 7$; $\mathrm{n}=10$ ) (frontal view). Interocular suture separated from antennal suture. Interocular distance $128(134 \pm 6 ; n=10)$. Clypeus 145 $(135 \pm 5 ; n=10)$ long. Flagellomeres: AIII $293(283 \pm 13 ; n=6)$, AIV $120(116 \pm 7 ; n=6)$, AV $125(120 \pm 6 ; n=6)$, AXV and AXVI missing. Ascoids simple and short, those on AIV not reaching the papilla level (Fig. 7). Papilla absent on AV (Fig. 8). Palpomere lengths: I 30 (31 \pm 1 ; n = 10), II 138 (124 \pm ; $n=6)$, III 175 (167 $\pm 7 ; n=6)$, IV $130(133 \pm 12 ; n=6)$, V 360 (353 $\pm 42 ; n=4)$. Palpal formula: 1.2.4.3.5. or 1. (2.4).3.5. Newstead's spines (about 10) distributed in two sets a little before the middle of palpomere III and about 4-5 near the top of palpomere II (Fig. 9). Labroepipharynx $185(187 \pm 10 ; n=10)$ long. Cibarium (Fig.11) with many reduced anterior teeth situated laterally and two more developed ones in the central part; four posterior (horizontal) teeth, many lateral greatly reduced teeth and a highly sclerotized projection, covered by reduced teeth between the innermost posterior teeth; pigment patch and posterior bulge well developed; arch incomplete. Pharynx (Fig. 11) armed. Labial sutures united. Maxilla: lacinia with 8 external teeth disposed in a longitudinal row and about 15 internal teeth. Hypopharynx (Fig. 10) with apicolateral teeth poorly delineated.

Cervix: ventrocervical sensillae present.

Thorax: mesonotum $555(546 \pm 31 ; \mathrm{n}=10)$ long. Pleurae with $5,7(2-8 ; n=10)$ proepimeral setae, $10(8-16 ; n=10)$ upper anepisternal setae and without metaepisternal setae $(0,1,2 ; \mathrm{n}=$ 10). Setae absent on the anterior katepisternum margin. Suture between katepimerum and metaepisternum absent. Wing (Fig. 12 ): length $1990(1920 \pm 121 ; n=9)$ and width $580(539 \pm 23 ; n$ $=8)$. Length of vein sections: alpha $550(453 \pm 47 ; n=9)$, beta $270(281 \pm 25 ; n=9)$, gamma 310 (301 $\pm 29 ; n=9)$, delta 240 (184 $\pm 27 ; \mathrm{n}=9)$, pi 130 (146 $\pm 13 ; \mathrm{n}=9)$, R5 1380 (1311 $\pm 78 ; \mathrm{n}=9$ ). 

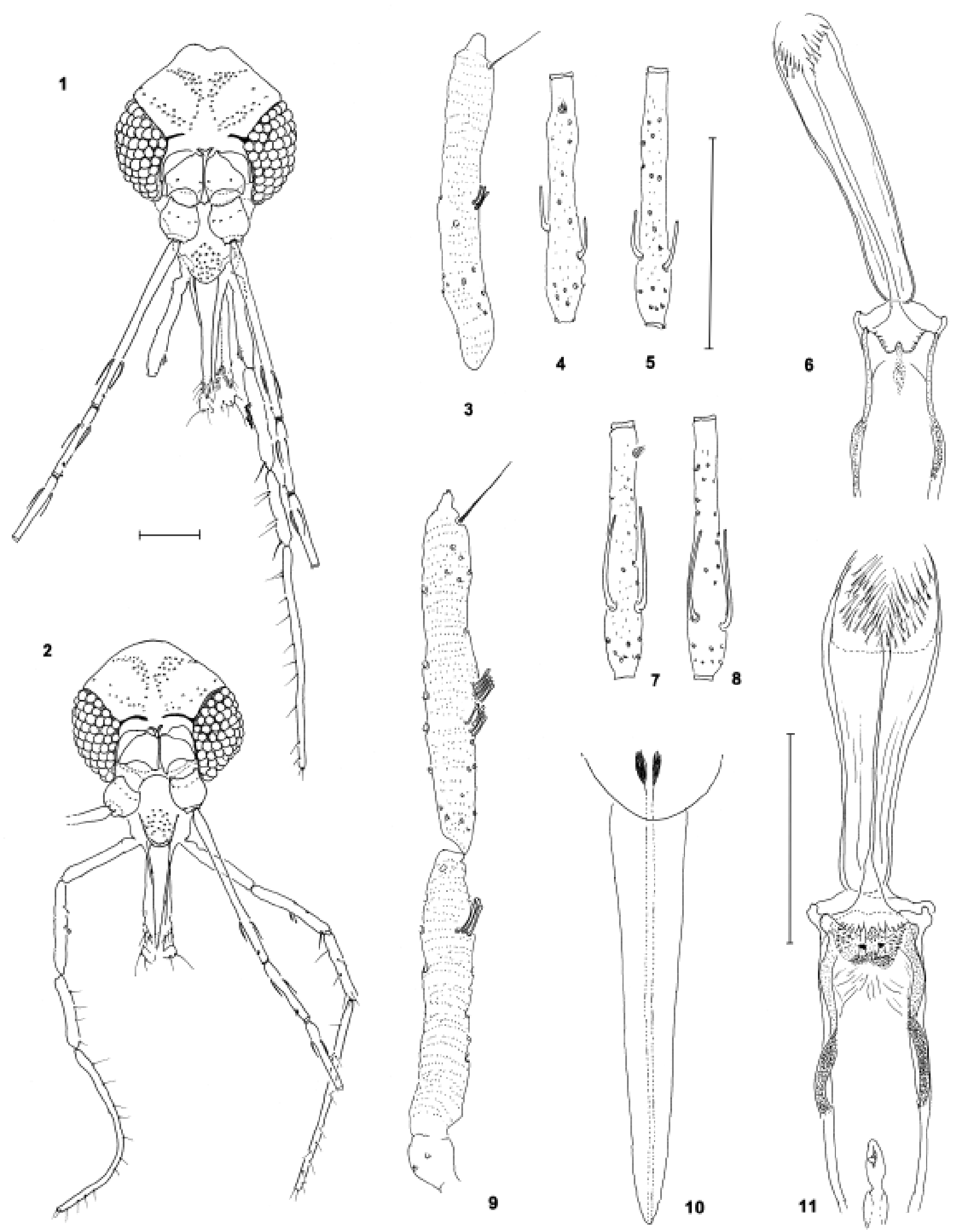

Figs. 1-11. Micropygomyia petari sp. nov. Head, frontal view: 1, holotype male; 2, paratype female. Figs. 3-6. Holotype male: 3, palpomere III; 4, antennomere IV; 5, antennomere V; 6, cibarium and pharynx. Figs. 7-11. Paratype female: 7, antennomere IV; 8, antennomere V; 9, palpomeres I, II and III; 10, hypopharynx; 11, cibarium and pharynx. Bar $=100 \mu \mathrm{m}$. 

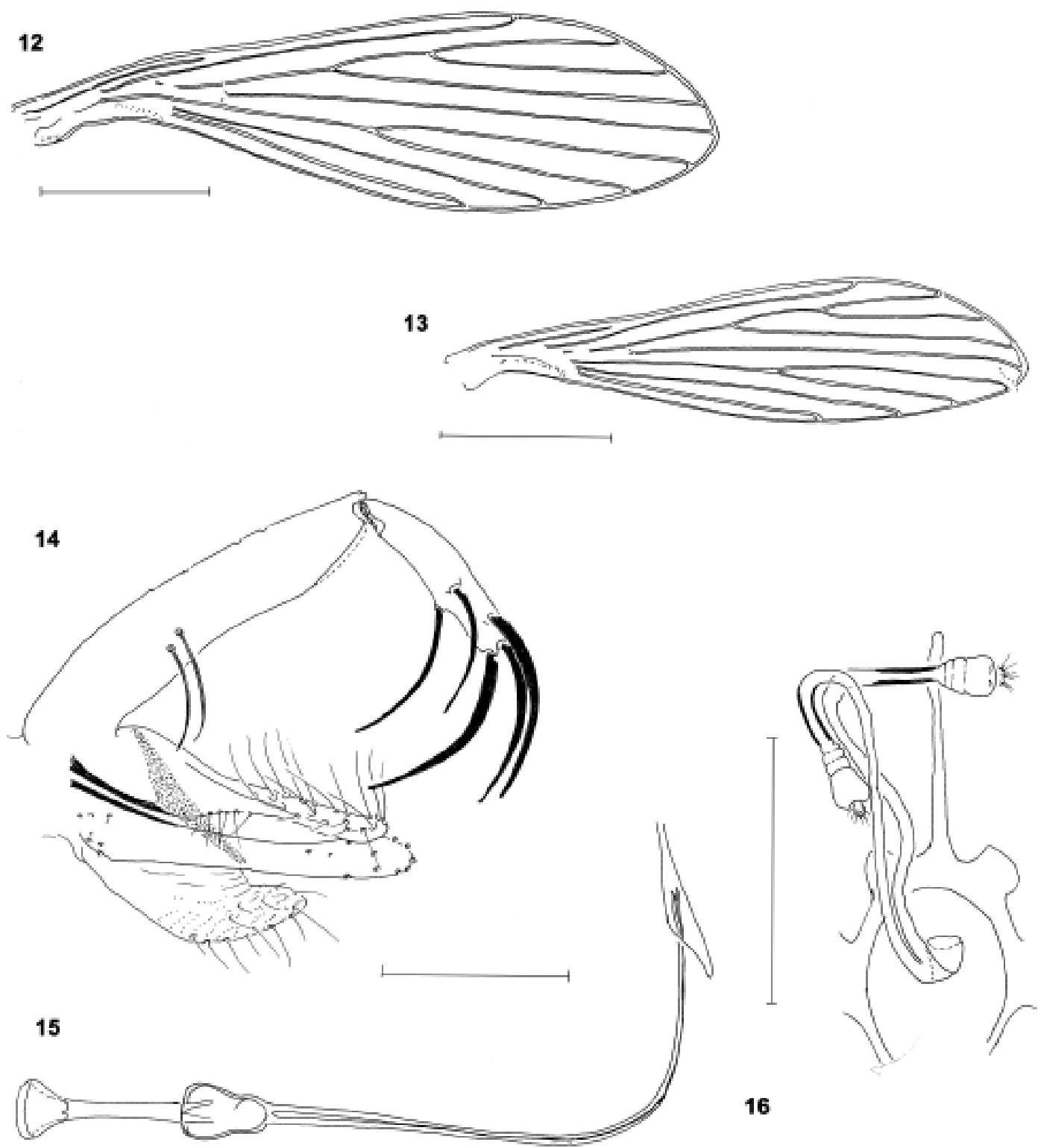

Figs. 12-16. Micropygomyia petari sp. nov. Wings: 12, paratype female; 13, holotype male. Figs. 14-15. Terminalia, holotype male: 14, genitalia; 15, aedeagus, genital pump and filaments. Fig. 16. Paratype female: genital fork and spermathecae. Bar $=100 \mu \mathrm{m}$.

Length of femora, tibiae, basitarsi and tarsi II+III+IV+V: foreleg 800, 920, 530, 670; midleg 810, 1080, 600, tarsi II+III+IV+V missing; hindleg 880, 1300, 710, 760 .

Abdomen length $1540(1530 \pm 131 ; n=9)$. Tergite VIII with $9(8-15 ; n=9)$ setae.

Spermathecae (Fig.16) with 3-4 annuli (33 long x 24 wide) with a wider apical ring; smooth individual ducts, 221 long $x$ wide and more sclerotised close to spermathecae; smooth common duct, 20 long x 18 wide. Cercus $140(144 \pm 13 ; n=9)$ long.

Holotype male. BRAZIL, São Paulo, Iporanga (Parque Estadual Turístico do Alto Ribeira - PETAR): in front of Santana cave,
16.XII.2001, black Shannon trap: 18h - 22h (FSP/USP). Paratypes, 4 males and 11 females (FSP/USP): 1 female, ibidem, 16/17.XII.2001, ALTm; 10 females and 2 males: on the track to Morro Preto cave: 1 female, 19/20.II.2001; 3 females, 1 male, 22/23.IV.2001; 1 female, 26/ 27.V.2001; 1 female, 24/25.VI.2001; 1 female, 1 male, 23/24.IX.2001; 2 females, 28/29.X.2001; 1 female, 24/25.XI.2001; 1 female, 16/ 17.XII.2001, ALTm. Ribeirão Grande (Parque Intervales), 1 male, 18.III.2001, in front of Minotauro cave, Shannon trap 19h - 21h; Colorida cave, 14/15.II.2001, ALTm. The type material was captured by E. A. B. Galati, A. M. Marassá, R. M. Gonçalves- Andrade and A. Galati.

\section{TAXONOMIC DISCUSSION}

The characteristics described above allowed us to include this new species in Micropygomyia (Sauromyia), oswaldoi 
series, in accordance with GaLATI (1995). Among the 19 species belonging to oswaldoi series, $M$. petari sp. nov. is very close to M. oswaldoi and to another species, both sexes of which were erroneously identified and redescribed by Diss et al. (1989) as Micropygomyia ferreirana (Barretto Martins \& Pellegrino, 1956) (GALATI et al. 2002). The presence of spines in the pharynx of both sexes of $M$. petari permits us to distinguish it from $M$. oswaldoi. From the taxon considered as $M$. ferreirana by DiAs et al. (1989) in both sexes, it is possible to differentiate $M$. petari by the length of AIII, which in the males of that species measures $239 \pm 10 ; n=4$; and in the females: $220 \pm 11 ; n=4$, thus shorter than that of $M$. petari ( $281 \pm 12 ; 283 \pm 13$, respectively) and further by the greater length of the gonocoxite (259 \pm 3 ), which in $M$. petari is $212 \pm 11$.

The association between male and female was based on the genital and extra-genital characteristics, coloration patterns and also on the fact that they were the unique representatives of the oswaldoi series in the captures made.

The name Micropygomyia petari alludes to the abbreviation of the Parque Estadual Turístico do Alto Ribeira (PETAR).

Acknowledgement. Financial support: FAPESP (process no. 00/ 06811-0).

\section{REFERENCES}

Barretto, M. P. 1962. Novos subgêneros de Lutzomyia França, 1924 (Diptera, Psychodidae, subfamília Phlebotominae). Revista do Instituto de Medicina Tropical de São Paulo 4(2): 91-100.

Cerqueira, N. C. 1943. Novo meio para a montagem de pequenos insetos em lâminas. Memórias do Instituto Oswaldo Cruz, 39(1): 3741.

Dias, E. S.; A. L. Falcão; J. E. Silva \& A. V. Martins. 1989. Redescrição do macho e descrição da fêmea de Lutzomyia (Helcocyrtomyia) ferreirana (Barretto, Martins \& Pellegrino, 1958) (Diptera, Psychodidae, Phlebotominae). Memórias do Instituto Oswaldo Cruz 84(2): 245-248

Dias, E. S.; A. L. Falcão; J. E. Silva \& A. V. Martins. 1991. Taxonomic studies of the subgenus Helcocyrtomyia. I. Series oswaldoi (Diptera, Psychodidae, Phlebotominae). Memórias do Instituto Oswaldo Cruz, 86(3): 323-340.

Forattini, O. P. 1973. Entomologia Médica. $4^{\circ}$ vol. Psychodidae. Phlebotominae. Leishmanioses. Bartonelose. São Paulo, Edgard Blücher/EDUSP, $658 \mathrm{p}$.

Galati, E. A. B. 1995. Phylogenetic systematics of Phlebotominae (Diptera, Psychodidae) with emphasis on American groups. Proceedings of the II International Symposium on Phlebotomine Sandflies. Boletín de la Dirección de Malariología y Saneamiento Ambiental, Maracay, 35 (Supl. 1): 133-142.

Galati, E. A. B.; V. L. B. Nunes; M. E. C. Dorval; G. Cristaldo; H. C. Rocha; R. M. GonÇalves-Andrade \& G. Naufel. 2001. Attractiveness of black Shannon trap for phlebotomines. Memórias do Instituto Oswaldo Cruz 96(5): 641-647.

Galati, E. A. B.; J. D. Andrade-Filho \& A. L. Falcão. 2002. Micropygomyia ferreirana (Barretto, Martins \& Pellegrino) as senior synonym of Micropygomyia borgmeieri (Martins, Falcão \& Silva) and denunciation of a error of identification related to this taxon, Entomología y Vectores 9(Supl. 1): 156-157.

Lewis, D. J.; D. G. Young; G. B. Fairchild \& D. M. Minter. 1977. Proposals for a stable classification of the sandflies (Diptera: Psychodidae). Systematic Entomology 2: 319-332.

Martins, A. V.; P. Williams \& A. L. Falcão.1978. American Sand Flies. Rio de Janeiro, Academia Brasileira de Ciências, 195 p.

Natal, D.; D. Marucci; I. M. Reis \& E. A. B. Galati. 1991. Modificação da armadilha CDC com testes para coletas de flebotomíneos (Diptera). Revista Brasileira de Entomologia 35(4): 697-700.

Theodor O. 1965. On the classification of American Phlebotominae. Journal of Medical Entomology 2(2): 171-197.

Veloso, H. P.; A. L. Rangel-Filho \& J. C. A. Lima. 1991. Classificação da vegetação brasileira, adaptada a um sistema universal. Rio de Janeiro, IBGE, Departamento de Recursos Naturais e Estudos Ambientais, 124 p.

Young, D. G. \& M. A. Duncan. 1994. Guide to the identification and geographic distribution of Lutzomyia sand flies in Mexico, the West Indies, Central and South America (Diptera:Psychodidae). Memoirs of the American Entomological Institute 54: 1-881. 